Journal of Applied Pharmaceutical Science Vol. 6 (05), pp. 058-062, May, 2016

Available online at http://www.japsonline.com

DOI: 10.7324/JAPS.2016.60509

ISSN 2231-3354 (cc) BY-NC-SA

\title{
Chemical and physical properties of Thai traditional shrimp paste $(\mathrm{Ka}-\mathrm{pi})$
}

\author{
Rungsima Daroonpunt ${ }^{1}$, Masataka Uchino ${ }^{2}$, Yoshimasa Tsujii ${ }^{2}$, Machiko Kazami ${ }^{2}$, Daiki Oka ${ }^{3}$, Somboon Tanasupawat ${ }^{1}$ * \\ ${ }^{1}$ Department of Biochemistry and Microbiology, Faculty of Pharmaceutical Sciences, Chulalongkorn University, Bangkok 10330, Thailand. ${ }^{2}$ Department \\ of Applied Biology and Chemistry, Tokyo University of Agriculture, 1-1-1 Sakuragaoka, Setagaya-ku, Tokyo 156-8502, Japan. ${ }^{3}$ Food Processing Center, \\ Tokyo University of Agriculture, 1-1-1 Sakuragaoka, Setagaya-ku, Tokyo 156-8502, Japan.
}

\section{ARTICLE INFO \\ Article history: \\ Received on: 03/02/2016 \\ Revised on: $27 / 02 / 2016$ \\ Accepted on: 31/03/2016 \\ Available online: $28 / 05 / 2016$}

Key words:

Shrimp paste, proximate

analyses, amino acids,

histamine, water activity.

\begin{abstract}
Thai traditional fermented shrimp paste (Ka-pi) is widely consumed as condiment and seasoning ingredient in Thailand. Chemical and physical properties of thirteen shrimp paste samples were examined. The water content and water activity $\left(A_{w}\right)$ of the products ranged from 33.95-52.19\% and 0.64-0.72, respectively while salt concentration was 7.00 to $10.85 \%$. The nitrogen content varied from 2.87 to $6.85 \%$ (w/w). KS1 showed the highest protein content $(42.8 \%)$ followed by SP1 and SP3 (42.4 and 41.3\%), respectively. The predominant amino acids were glutamic acid (70.1-593.9 $\mu \mathrm{g} / \mathrm{g})$, lysine $(112.7-546.3 \mu \mathrm{g} / \mathrm{g})$ and leucine $(29.5-544.9 \mu \mathrm{g} / \mathrm{g})$. Total bacterial cell count in the samples ranged from $1.3 \times 10^{3}-2.9 \times 10^{5} \mathrm{cfu}^{-1}$ while lactic acid bacteria (LAB) were not detected. This study will be provided the information for improving the quality of products in manufacture to meet the demand of consumer.
\end{abstract}

\section{INTRODUCTION}

The traditional fermented shrimp paste (Ka-pi), a purple-pink to dark brown color, strong odor and paste-like consistency is widely consumed as seasoning ingredient in Thailand. In Southeast Asia, there are the distinguished names of this fermented product such as bagoong (Philippines), shiokara (Japan), mam ruoc (Vietnam), terasi (Indonesia), ngapi (Myanmar) and belacan (Malaysia) (Wittanalai et al., 2011; Chaijan and Panpipat, 2012). Ka-pi is made from small sized shrimps (Acetes spp.) (Hajeb and Jinap, 2012). It depends on the types of shrimps available in each country and then mixed with salt and sun dried for 2 days. These dried shrimps are then ground into a fine paste and fermented 2 days, and put into the jar before fermenting for at least 2 months (Wittanalai et al., 2011; Chuon et al., 2014). During fermentation, the protein

Corresponding Author

Somboon Tanasupawat, Department of Biochemistry and Microbiology, Faculty of Pharmaceutical Sciences, Chulalongkorn University, 254 Phayathai Road, Wangmai, Bangkok 10330, Thailand.

E-mail:Somboon.T@chula.ac.th hydrolysis of shrimp paste is mediated by the action of indigenous and microbial proteases yield short chain peptides and free amino acids which enhance the flavor and taste (Chaijan and Panpipat, 2012; Hajeb and Jinap, 2012). Therefore, the shrimp paste is a good source of peptide and amino acids. In Malaysia, belacan contains free glutamic acid more than 4,200 mg/100 g (Hajeb and Jinap, 2012). However, a little information regarding the chemical and physical properties of Thai shrimp paste (Ka-pi) has been reported. Thus, the objective of this study was to determine the chemical and physical properties including the microbiological property of shrimp paste collected from Nakhon Sri Thammarat province in Thailand.

\section{MATERIALS AND METHODS Sample collection}

Two and eleven shrimp paste (Ka-pi) samples were collected from Songkhla and Nakhon Sri Thammarat provinces in Thailand, respectively. These samples were directly obtained from the market and supermarket which packed in plastic bag at room temperature, and they were maintained at $4{ }^{\circ} \mathrm{C}$ until analysed. 
Microbial and chemical analyses were immediately performed after the samples were brought to the laboratory (within several days). Fermentation period, sampling location and other information are provided in Table 1. Ten samples of Kapi (indicated as SP) were collected from the markets and three samples (indicated as KS) were collected from the supermarkets.

\section{Proximate analyses}

Shrimp paste samples (5 g) were homogenized thoroughly with $25 \mathrm{ml}$ of distilled water (w/v) prior to determine salt concentration and $\mathrm{pH}$. Salt concentration was measured by handy salt concentration meter (APAL-ES2, AS ONE) and $\mathrm{pH}$ was measured by $\mathrm{pH}$ meter (C-62, AS ONE). Water content was determined by using moisture analyzer (AND MX-50 using manual) while water activity $\left(A_{w}\right)$ of each sample was measured at $25{ }^{\circ} \mathrm{C}$ using a water activity analyzer (Aw SPRINT TH-500, Novasina AG, Switzerland). Nitrogen content (N-content) analysis was performed by using an automated nitrogen and carbon analyzer (Sumigraph NC-220F, Sumika Chemical Analysis Service, Ltd.). Protein was calculated by $6.25 \mathrm{x}$ N-content.

\section{LC/MS measurement of free amino acids}

In brief, free amino acids were extracted from shrimp paste. Samples were diluted 1:100 with pure water and centrifuged for $15 \mathrm{~min}$ at $15,000 \mathrm{rpm}$ and $4{ }^{\circ} \mathrm{C}$. The supernatant was passed through a $0.20 \mu \mathrm{m}$ filter (Kurabo, Osaka, Japan); the filtrate was injected directly into an Accurate-Mass Q-TOF LC/MS with an Agilent 6530 (Agilent Technologies, Santa Clara, CA, USA) coupled to an Agilent 1260 Infinity HPLC (Santa Clara, CA, USA). To identify the Amino Acid Standard (Agilent Technologies, Logistics Center - USA). The accurate mass data was detected at high resolution and high mass accuracy ( $\pm 2 \mathrm{ppm})$, which was essential for accurate chemical formula assignment.

Total ion spectra were collected over a mass range of $\mathrm{m} / \mathrm{z}$ 60-400 in positive mode at an acquisition rate of $5.0 \mathrm{spectra} / \mathrm{s}$. The drying gas temperatures and flow rate were $300{ }^{\circ} \mathrm{C}$ and 6.0 $\mathrm{L} / \mathrm{min}$, respectively. The sheath gas temperature and flow rate were $350{ }^{\circ} \mathrm{C}$ and $12.0 \mathrm{~L} / \mathrm{min}$, respectively. The nebulizer gas pressure, skimmer voltage, octopole RF, and fragmentor voltage were $50 \mathrm{psi}, 60 \mathrm{~V}, 750 \mathrm{~V}$, and $110 \mathrm{~V}$, respectively. The capillary voltage was $3.5 \mathrm{kV}$. Continuous internal calibration was performed during analysis to achieve the desired mass accuracy of recorded ions with the ions of $\mathrm{m} / \mathrm{z}$ of 112.9855. Chromatographic separation of the analytes was done using an Intrada Amino Acid (50 x $3 \mathrm{~mm}$ i.d., particle size $3.0 \mu \mathrm{m}$ ) (Imtakt Corpration, Kyoto) using $100 \mathrm{mM}$ ammonium formate (A) and acetonitrile/formic acid $0.1 \%(\mathrm{v} / \mathrm{v})(\mathrm{B})$ as eluent. A gradient was delivered at 600 $\mu \mathrm{l} / \mathrm{min}$ starting from $86 \%$ phase $\mathrm{B}$; it was maintained for $3 \mathrm{~min}$ at $86 \%$ phase $\mathrm{B}$ and then raised to $100 \%$ in $10 \mathrm{~min}$; and then the column was equilibrated back to the initial condition in $4 \mathrm{~min}$. Thus, the total analysis time was 14 min, including column washing and re-equilibration. All data, acquired in the positive ion mode, were collected and processed using MassHunter Workstation Software Quantitative Analysis ver. B.07.00 for TOF software (Agilent Technologies).

\section{Measurement of color}

Color of shrimp paste samples were measured by spectrophotometer CM-5 (Konika Minolta) and reported in the CIE system. $L^{*}$ (lightness), $a^{*}$ (redness/greenness), and $b^{*}$ (yellowness/blueness).

\section{Histamine analysis}

Histamine concentration of shrimp paste samples was determined by colorimetric enzymatic assay (Kikoman Biochemifa Company, Japan, 2014). The colored tetrazolium salt was created in the presence of 1-methoxy-5-methylphenazinium methylsulfate (1-methoxy PMS) and measured at $470 \mathrm{~nm}$.

\section{Bacterial cell count}

A $1 \mathrm{~g}$ of sample stored in a refrigerator was homogenized with $9 \mathrm{ml}$ normal saline containing $8.5 \mathrm{~g} \mathrm{~kg}^{-1} \mathrm{NaCl}$. Ten-fold dilutions of homogenates $(100 \mu \mathrm{l})$ were spread on standard agar medium (composed of $5.0 \mathrm{~g}$ peptone, $2.0 \mathrm{~g}$ yeast extract, $1.0 \mathrm{~g}$ glucose and $15.0 \mathrm{~g}$ agar in $1 \mathrm{~L}$ distilled water) for general bacteria and de Man, Rogosa, and Sharpe (MRS) agar medium for lactic acid bacteria (LAB), and incubated at $30{ }^{\circ} \mathrm{C}$ for 2-7 days. Viable counts (colony-forming unit; cfu) were reported.

Table 1: Location and fermentation period of Thai traditional shrimp paste (Ka-pi).

\begin{tabular}{cclc}
\hline $\begin{array}{c}\text { Sample } \\
\text { source }\end{array}$ & $\begin{array}{c}\text { Sample } \\
\text { no. }\end{array}$ & \multicolumn{1}{c}{ Sampling location } & $\begin{array}{c}\text { Fermentation } \\
\text { period }\end{array}$ \\
\hline & SP1 & Amphoe Meuang, Nakhon Sri Thammarat province & $<2$ months \\
& SP2 & Amphoe Khanom, Nakhon Sri Thammarat province & $<2$ months \\
& SP3 & Tambon Banglaung, Amphoe Meuang, Nakhon Sri Thammarat province & $<1$ month \\
& SP4 & Amphoe Tha sala, Nakhon Sri Thammarat province & $<$ month \\
Local market & SP5 & Amphoe Satingpra, Songkhla province & $<2$ months \\
& SP6 & Amphoe Pak Phanang, Nakhon Sri Thammarat province & $<2$ months \\
& SP7 & Amphoe Hua Sai, Nakhon Sri Thammarat province & $<3$ months \\
& SP8 & Amphoe Sichon, Nakhon Sri Thammarat province & 3 months \\
& SP9 & Tambon Pak Nakhon, Amphoe Meuang, Nakorn Sri Thammarat province & Several months \\
& SP10 & Songkhla province & Several months \\
Supermarket & KS & M-Peaw Brand, Kapi Chumchon Bangyai, Tambon Bangchak, Amphoe Meuang, Nakhon Sri Thammarat province \\
& KS2 & Tonmai and Konmek shop, Amphoe Ronpiboon, Nakhon Sri Thammarat province & Several months \\
\hline
\end{tabular}


Table 2: Proximate composition of Thai shrimp paste (Ka-pi).

\begin{tabular}{|c|c|c|c|c|c|c|}
\hline Sample no. & Water ${ }^{*}$ content $(\%)$ & Water activity ${ }^{*}\left(A_{w}\right)$ & Salt Concentration ${ }^{*}(\%)$ & pH $^{*}$ & N-content ${ }^{*}(\%)$ & Protein $^{*}(\%)$ \\
\hline SP1 & 46.32 & $0.65 \pm 0.001$ & 7.15 & 7.67 & 6.79 & 42.4 \\
\hline SP2 & 44.64 & $0.66 \pm 0.005$ & 7.00 & 6.96 & 5.55 & 34.7 \\
\hline SP3 & 36.63 & $0.65 \pm 0.001$ & 8.90 & 8.31 & 6.61 & 41.3 \\
\hline SP4 & 33.95 & $0.64 \pm 0.003$ & 8.65 & 8.11 & 6.23 & 38.9 \\
\hline SP5 & 42.52 & $0.68 \pm 0.001$ & 8.90 & 7.81 & 4.75 & 29.7 \\
\hline SP6 & 45.49 & $0.69 \pm 0.001$ & 8.90 & 7.04 & 2.87 & 17.9 \\
\hline SP7 & 45.74 & $0.68 \pm 0.002$ & 9.05 & 6.94 & 3.19 & 19.9 \\
\hline SP8 & 52.19 & $0.72 \pm 0.001$ & 7.54 & 7.02 & 4.76 & 29.8 \\
\hline SP9 & 48.53 & $0.70 \pm 0.001$ & 8.60 & 7.05 & 3.83 & 23.9 \\
\hline SP10 & 46.72 & $0.68 \pm 0.002$ & 9.50 & 7.84 & 6.15 & 38.4 \\
\hline KS1 & 44.54 & $0.66 \pm 0.006$ & 10.85 & 7.72 & 6.85 & 42.8 \\
\hline KS2 & 48.95 & $0.69 \pm 0.001$ & 10.15 & 7.73 & 4.47 & 27.9 \\
\hline KS3 & 47.69 & $0.68 \pm 0.000$ & 8.25 & 7.35 & 4.68 & 29.2 \\
\hline
\end{tabular}

*Standard variation value $<0.01$

\section{RESULTS AND DISCUSSION}

\section{Samples collection}

Ten and three samples of shrimp paste were collected from the local market and the supermarket in Thailand, respectively. Sample number, SP1, SP2, SP3, SP4, SP6, SP7, SP8, SP9, KS1, KS2 and KS3 were collected from Nakhon Sri Thammarat province while SP5 and SP10 were collected from Songkhla province (Table 1).

\section{Proximate analyses}

The water content and water activity $\left(A_{w}\right)$ of the shrimp paste samples collected from the local market were 33.95-52.19\% and 0.64-0.72 while the samples from supermarket were 44.54$48.95 \%$ and $0.66-0.69$, respectively (Table 2). $A w$ of local products has wide range compared with those from supermarket. Local products were homemade or small lot, therefore some ingredients were different among the samples. $A_{w}$ can be related to the consistency of shrimp paste which varied from soft and pasty to dry and hard. $A_{w}$ of the final shrimp paste product depend on period which the sample was dried under the sun (Pongsetkul et al., 2014). The shrimp paste can be classified as an intermediate moisture food, with an $A_{w}$ of about 0.7 (Fennema, 1996). The low $A_{w}$ of shrimp paste products could be associated with increase the shelf-life and preserve the product from microbial spoilage at ambient temperature (Goulas and Kontominas, 2005; Prapasuwannakul and Suwannahong, 2015). In addition, the low $A_{w}$ would prevent rancidity of the product and limited the growth of food pathogens (Hajeb and Jinap, 2012). Thirteen shrimp paste samples contained salt which is needed for preservation. Salt concentration ranged from 7.00 to $10.85 \%$. Moreover, the salt content would enhance both the shelf-life and the flavor of shrimp paste products. All shrimp paste samples had a neutral to slightly alkaline $\mathrm{pH}$ ranging from 7.02-8.31. The slightly alkaline might have been caused by the formation of volatile base compounds such as ammonia or other degradation products, the degradation products generated during fermentation. The shrimp paste collected from the local market contained 2.87-6.79 \% of $\mathrm{N}$ content and 23.9-42.4\% protein while the local market contained 4.47-6.85\% of N-content and 27.9-42.8\% protein.
The samples contained nitrogen content varied from 2.87 to $6.85 \%$. Generally, the nitrogen content has been used to indicate the degree of protein hydrolysis. Thus, nitrogen content can be the indicator for the level of the cleavage of peptides (Angeles and Garcia-Carreno, 2002). The highest nitrogen contents were 6.85, 6.79 and $6.61 \%$ in KS1, SP1 and SP3 samples, respectively. This was higher than the nitrogen contents found in fish sauce which ranged from 0.3 to $3.0 \%$ (w/v) (Park et al., 2001; Tungkawachara et al., 2003; $\mathrm{Xu}$ et al., 2008). In addition, the nitrogen content in soy sauce was 3 to $10 \%$ (dried; w/w). Therefore, nitrogen content of the samples was in the range of liquid seasoning. The protein content ranged from 17.9-42.8\%. The sample KS1 showed the highest protein content (42.8\%) followed by 42.4 and $41.3 \%$, in SP1 and SP3, respectively. So, the protein content could be indicated the good source of proteins.

\section{Free amino acid content}

The amino acid contents of the shrimp paste collected from the local market and the supermarket were variable (Table 3 ). The predominant amino acids of thirteen shrimp paste products were glutamic acid $(70.1-593.9 \mu \mathrm{g} / \mathrm{g})$, lysine $(112.7-546.3 \mu \mathrm{g} / \mathrm{g})$ and leucine (29.5-544.9 $\mu \mathrm{g} / \mathrm{g}$ ) (Table 3), compared to the content of glutamic acid in shrimp paste and fish sauce which ranged from 3.1-7.0 \% (w/w) and 0.5-1.5\% (w/v), respectively (Kim et al., 2014; Park et al., 2001) while to the Cambodian traditional fermented fish products which contained $4.9 \mathrm{~g} \mathrm{~kg}^{-1}$ glutamic acid as reported by Chuon et al. (2014). SP4 was showed highest glutamic acid followed by KS1 and SP2 that agreed with our study. The high amounts of glutamic acid were indicated the rich of umami taste.

In 1990, Kim and Rhee reported that arginine, aspartate, isoleucine, lysine, proline, serine, threonine and valine were related to taste and flavor. Some amino acids, alanine, glycine, serine, threonine and valine were related to sweet taste while arginine, histidine, isoleucine, leucine, methionine, phenylalanine and tryptophan are related to bitter taste. In addition, $\gamma$ aminobutyric acid (GABA) was detected in all samples (0.7-2.6 $\mu \mathrm{g} / \mathrm{g}$ ). The GABA containing in food has reported to play role as health benefits in many kinds of fermented products (Dhakal et al., 2012). 
Table 3: Amino acid contents $(\mu \mathrm{g} / \mathrm{g})$ of Thai shrimp paste $(\mathrm{Ka}-\mathrm{pi})$.

\begin{tabular}{|c|c|c|c|c|c|c|c|c|c|c|c|c|c|c|c|}
\hline $\begin{array}{c}\text { Sample } \\
\text { no. }\end{array}$ & Phe & Leu & Ile & Met & Pro & Val & Ala & Glu & Gly & Gln & Asp & His & Lys & Arg & GABA \\
\hline SP1 & 112.1 & 296.1 & 197.9 & 97.3 & 99.0 & 161.4 & 173.9 & 83.2 & 137.6 & 16.2 & 212.4 & 27.5 & 311.9 & 41.5 & 1.9 \\
\hline SP2 & 118.7 & 252.3 & 158.0 & 66.1 & 74.6 & 142.9 & 147.2 & 524.8 & 98.4 & 14.6 & 129.2 & 15.8 & 196.6 & 30.8 & 1.9 \\
\hline SP 3 & 131.6 & 324.6 & 183.0 & 95.6 & 71.8 & 160.5 & 162.8 & 399.1 & 187.9 & 5.2 & 151.6 & 23.7 & 301.4 & 22.0 & 2.1 \\
\hline SP 4 & 164.7 & 454.8 & 264.5 & 124.2 & 93.8 & 212.3 & 229.2 & 593.9 & 220.3 & 9.4 & 221.7 & 32.1 & 458.0 & 30.5 & 2.6 \\
\hline SP 5 & 56.8 & 135.4 & 82.7 & 38.7 & 64.6 & 90.2 & 118.7 & 298.3 & 94.9 & 5.8 & 139.8 & 11.3 & 165.6 & 24.9 & 1.5 \\
\hline SP 6 & 79.8 & 166.4 & 84.4 & 44.7 & 48.5 & 93.4 & 101.5 & 70.1 & 80.6 & 14.4 & 96.5 & 12.1 & 143.1 & 50.2 & 0.7 \\
\hline SP 7 & 121.2 & 301.5 & 200.7 & 86.2 & 68.3 & 149.7 & 126.9 & 310.7 & 89.3 & 2.2 & 174.4 & 11.3 & 196.7 & 10.0 & 1.1 \\
\hline SP 8 & 179.9 & 383.6 & 237.2 & 113.6 & 33.8 & 204.8 & 174.5 & 427.5 & 133.0 & 11.3 & 209.8 & 27.8 & 315.0 & 28.9 & 2.0 \\
\hline SP 9 & 123.1 & 246.5 & 140.5 & 76.4 & 66.3 & 143.2 & 120.5 & 253.9 & 97.1 & 6.2 & 155.1 & 12.9 & 195.7 & 18.2 & 1.0 \\
\hline SP 10 & 255.8 & 544.9 & 364.3 & 162.9 & 135.4 & 269.7 & 245.0 & 260.8 & 206.6 & 46.0 & 281.7 & 37.6 & 546.3 & 224.4 & 2.6 \\
\hline KS1 & 153.0 & 277.9 & 139.1 & 77.2 & 107.3 & 205.5 & 182.3 & 591.3 & 136.1 & 18.3 & 274.7 & 41.3 & 376.7 & 56.1 & 2.6 \\
\hline $\mathrm{KS} 2$ & 114.6 & 297.1 & 168.1 & 70.4 & 70.2 & 128.3 & 140.5 & 450.9 & 109.0 & 29.0 & 169.5 & 31.5 & 229.6 & 138.2 & 1.4 \\
\hline KS3 & 13.4 & 29.5 & 18.5 & 8.2 & 28.3 & 29.5 & 90.1 & 151.9 & 93.4 & 7.4 & 124.2 & 11.1 & 112.7 & 33.8 & 1.3 \\
\hline
\end{tabular}

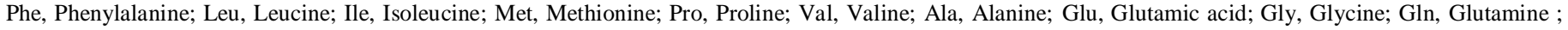
Asp, Aspartic acid; His, Histidine; Lys, Lysine; Arg, Arginine; GABA, gamma-Aminobutyric acid

From our results, the high nitrogen content of the samples indicated the cleavage of peptides to high amount of free amino acids (Angeles and Garcia-Carreno, 2002). However, only samples SP1 and SP6 that showed low glutamic acid content compared to the other samples.

\section{Measurement of color}

The different shrimp paste products had different colors, $L^{*}$ (lightness), $a^{*}$ (redness) and $b^{*}$ (yellowness) ranged from 29.639.48, 6.01-9.15 and 8.33-17.91, respectively. These samples were purple-brown to dark brown in color. The difference in color might be caused by the difference pigment contents in raw materials, process as well as ingredients added. The carbonyl groups of aldehydes and ketone, the oxidation products, could react with amino groups of free amino acids or peptides generated during hydrolysis, leading to yellow or brown color development (Yarnpakdee et al., 2014). Brown development of shrimp paste products may be occurred by enzymatic and non-enzymatic reactions such as active polyphenoloxidase or Maillard reaction. Moreover, the oxidation of free astaxanthin resulted in the pale discoloration of products (Chaijan and Pannipat, 2012).

Table 4: CIELAB colorimetric values of Thai shrimp paste (Ka-pi).

\begin{tabular}{cccc}
\hline Sample no. & $\boldsymbol{L}^{*}$ & $\boldsymbol{a}^{*}$ & $\boldsymbol{b}^{*}$ \\
\hline SP1 & 39.22 & 6.78 & 14.62 \\
SP2 & 35.51 & 8.5 & 12.67 \\
SP3 & 34.37 & 6.01 & 9.23 \\
SP4 & 32.6 & 6.34 & 8.33 \\
SP5 & 35.87 & 6.74 & 12.5 \\
SP6 & 29.6 & 8.28 & 10.8 \\
SP7 & 30.61 & 7.03 & 9.04 \\
SP8 & 32.93 & 9.51 & 9.58 \\
SP9 & 29.78 & 9.2 & 11.07 \\
SP10 & 39.48 & 7.91 & 10.4 \\
KS1 & 36.76 & 6.4 & 12.39 \\
KS2 & 32.89 & 8.66 & 10.36 \\
KS3 & 28.56 & 8.29 & 17.91 \\
\hline
\end{tabular}

$L^{*}$, lightness; $a^{*}$, redness-greenness; $b^{*}$, yellowness-blueness Standard variation value $<0.01$

\section{Histamine analysis}

The histamine concentration of the shrimp paste collected from the local market and the supermarket ranged from
$<20-46.70$ and 25.11-53.85 ppm, respectively (Table 5). The histamine detected was below the limit of $200 \mathrm{ppm}$ according to Codex Alimentarius (Vallejos et al., 2012) that would not exhibited the toxicity. Low histamine content here supported the procedure used for shrimp paste production as the shrimps were immediately mixed with salt at the time that the raw materials reached the shore because histamine associated with incorrect handling and the storage of raw materials (Pilapil et al., 2015). The level of histamine of all samples were differed which can be attributed to differences in quality of the raw materials, endogenous microflora, improper handling and environment during the production and the free amino acids (histidine) presented as a precursors (Singh et al., 2012).

Table 5: Histamine and bacterial numbers of Thai shrimp paste (Ka-pi).

\begin{tabular}{ccc}
\hline Sample no. & $\begin{array}{c}\text { Histamine } \\
\text { conc. }(\mathbf{p p m})\end{array}$ & $\begin{array}{c}\text { Bacterial } \\
\text { cell number }(\mathbf{c f u} / \mathbf{g})\end{array}$ \\
\hline SP1 & 46.70 & $2.9 \times 10^{4}$ \\
SP2 & 30.73 & $1.7 \times 10^{4}$ \\
SP3 & 29.19 & $1.3 \times 10^{3}$ \\
SP4 & 31.06 & $2.1 \times 10^{3}$ \\
SP5 & 32.60 & $3.4 \times 10^{4}$ \\
SP6 & $<20$ & $8.2 \times 10^{4}$ \\
SP7 & 26.65 & $4.3 \times 10^{4}$ \\
SP8 & $<20$ & $6.1 \times 10^{4}$ \\
SP9 & 24.45 & $6.8 \times 10^{4}$ \\
SP10 & 29.19 & $1.3 \times 10^{5}$ \\
KS1 & 30.29 & $2.9 \times 10^{5}$ \\
KS2 & 53.85 & $7.0 \times 10^{4}$ \\
KS3 & 25.11 & $1.1 \times 10^{5}$
\end{tabular}

\section{Bacterial cell count}

Total bacterial cell count of the samples varied from $1.3 \times 10^{3}$ to $2.9 \times 10^{5} \mathrm{cfu} \mathrm{g}^{-1}$ while the number of lactic acid bacteria (LAB) in thirteen shrimp paste products was not detected (Table 5). Based on $A_{w}$, bacteria distributed as the rest cell or spore. Therefore, these shrimp pastes are stable for long period though the maximum bacterial number was $10^{5}$ order.

As mentioned above, the water content, water activity $\left(A_{w}\right)$, N-content, protein, amino acids content and histamine concentration of the shrimp paste samples collected from the local market and the supermarket were variable based on the raw 
materials that may due to the different sources upon factories. Based on our data, quality of shrimp paste may be controlled by salt concentration, water content and fermentation period. Therefore, the analysis of chemical properties of Ka-pi from the different factories and provinces used should be further more studied in the view point of application.

\section{CONCLUSION}

The differences of shrimp paste samples were variable in compositions. They contained major protein component that indicated the good sources of proteins and amino acids. In addition, the low $A_{w}$ and low histamine concentration but the high salt content, therefore, these products would become stable for a long period. In this study, the insights on Thai shrimp paste products acquired will help to both establish the basic scientific information of these products and also the future of manufacturing.

\section{ACKNOWLEDGEMENTS}

This study was supported by the Thailand Research Fund for a 2012 Royal Golden Jubilee Scholarship as a research grant to R. D. We would like to thank Dr. Hiroyuki Oshima, Department of Applied Biology and Chemistry, Tokyo University of Agriculture, for nitrogen content analysis.

\section{REFERENCES}

Angeles Navarrete del Toro M, Garcia-Carreno FL. 2002. Evaluation of the progress of protein hydrolysis. In: Wrolstad RE et al eds. Current protocols in food analytical chemistry. Wiley, New York.

Chaijan M, Panpipat W. Darkening prevention of fermented shrimp paste by pre-soaking whole shrimp paste with pyrophosphate. As J Food Ag-Ind, 2012; 5(2): 163-171.

Chuon MR, Shimoto M, Koyanagi T, Sasaki T, Michihata T, Chan S, Mao S, Enomoto T. Microbial and chemical properties of Cambodian traditional fermented fish products. J Sci Food Agric, 2014; 94: 1124-1131.

Dhakal R, Bajpai VK, Baek K-H. Production of gaba $(\gamma-$ Aminobutyric acid) by microorganisms: a review. Braz J Microbiol. 2012; 43(4): 1230-1241.

Fennema OR. 1996. Water and ice. In: Fennema OR ed. Food chemistry. Marcel Dekker, New York, pp. 17-94.

Goulas AE, Kontominus MG. Effect of salting and smokingmethod on the keeping quality of chub mackerel (Scomber japonicus): biochemical and sensory attributes. Food Chem, 2005; 93: 511-520.
Hajep P, Jinap S. Fermented shrimp paste products as source of umami in Southeast Asia. J Nutr Food Sci, 2012; S10:006. doi: 10.4172/2155-9600.S10-006.

Kim MJ, Rhee HS. Studies on the changes of taste compounds during soy paste fermentation. Kor J Soc Food Sci, 1990; 60: 1-8.

Kim Y-B, Choi Y-S, Ku S-K, Jang D-J, Ibrahim HH, Moon KB. Comparison of quality characteristics between belacan from Brunei Darussalam and Korean shrimp paste. J Ethn Foods, 2014; 1: 19-23.

Park J-N, Fukumoto Y, Fujita E, Tanaka T, Washio T, Otsuka S, Shimizu T, Watanabe K, Abe H. Chemical Composition of Fish Sauces Produced in Southeast and East Asian Countries. J Food Comp Anal, 2001; 14: 113-125.

Pilapil AR, Neyrinck E, Deloof D, Bekaert K, Robben J, Raes $\mathrm{K}$. Chemical quality assessment of traditional salt-fermented shrimp paste from Northern Mindanao, Philippines. J Sci Food Agric, 2015; doi 10.1002/jsfa.7167.

Pongsetkul J, Benjakul S, Sampavapol P, Osako K, Faithong N. Chemical composition and physical properties of salted shrimp paste (Kapi) produced in Thailand. Int Aquat Res, 2014; 6: 155-166.

Prapasuwannakul N, Suwannahong K.Chemical composition and antioxidant activity of Klongkone shrimp paste. Procedia Soc Behav Sci, 2015; 197: 1095-1100

Singh VP, Pathak V, Verma AK. Fermented meat products: organoleptic qualities and biogenic amines - a review. Am J Food Technol, 2012; 7: 278-288

Tungkawachara S, Park JW, Choi YJ. Biochemical properties and consumer acceptance of pacific whiting fish sauce. Food Chem Toxicol, 2003; 68: 855-860.

Vallejos MJM, Pham LJ, Barraquio VL. Biogenic amines in some natural and processed cheeses sold in Laguna Province, Philippines. Philipp J Sci, 2012; 141: 111-115.

Wittanalai S, Rakariyatham N, Deming RL. Volatile compounds of vegetarian soybean kapi, a fermented Thai food condiment. Afr J Biotechnol, 2011; 10: 821-830.

Xu W, Yu G, Xue C, Xue Y, Ren Y. Biochemical changes associated with fast fermentation of squid processing by-products for low salt fish sauce. Food Chem, 2008; 107: 1597-1604.

Yarnpakdee S, Benjakul S, Penjamrus P, Kristinsson HG. Chemical compositions and muddy flavour/odour of protein hydrolysate from Nile tilapia and broadhead catfish mince and protein isolate. Food Chem, 2014; 142: 210-216.

\section{How to cite this article:}

Daroonpunt R, Uchino M, Tsujii Y, Kazami M, Oka D, Tanasupawat S. Chemical and physical properties of Thai traditional shrimp paste (Ka-pi). J App Pharm Sci, 2016; 6 (05): 058-062. 